I. І. Сараненко, Н. М. Цвєткова, А. О. Дубина

Дніпропетровський національний університет

\title{
ФІЗИКО-ХІМІЧНІ ТА МОРФОЛОГІЧНІ ВЛАСТИВОСТІ ГРУНТІВ ПІВНІЧНОЇ ТЕХНОЗОНИ М. КРЕМЕНЧУК
}

3'ясовано, що природний грунтовий покрив на більшій частині технозони знищений або значно змінений: спостерігається переущільнення, перемішування майже всіх горизонтів грунтового профілю. Вміст антропогенних включень становить 25-50 \%. На основі отриманих результатів та із використанням класифікації міських грунтів встановлені підтипи грунтів: індустроземи, культуроземи, ристоземи, урбодернові грунти.

Natural soil cover has been removed or changed by overconsolidation and agitation of almost all layers of the soil profile at the most part of the technozone of Kremenchuk town. The content of anthropogenic inclusions makes up $25-50 \%$. On the basis of obtained data and using classification of urban soils the subtypes of existing soils are represented.

\section{Вступ}

У міських екосистемах швидкість, склад і властивості грунтових процесів значно відрізняються від природних, де еволюція та розвиток процесів протікають повільно, а грунт встигає пристосуватися до них. Міські системи відрізняються від природних тим, що вони постійно піддаються катастрофічним впливам із високим ступенем інтенсивності [9], що часто призводить до загибелі самої системи та утворення нової та, відповідно, формування нового грунтового покриву [10]. Основна форма існування міських грунтів - постійні порушення, перемішування стороннього матеріалу [5].

М. М. Строгановою [6] розроблено схему трансформації та деградації функцій грунтового покриву, а Д. Г. Тихоненко [7] вдосконалив класифікацію грунтів України. А. П. Травлєєв і О. В. Мірзак [4] доповнили класифікацію грунтів М. М. Строганової та, з урахуванням особливостей степової зони України, відзначили, що механічне, хімічне, фізичне, біологічне ушкодження грунтів призводить до погіршення їх фізико-хімічних властивостей, а згодом - і до невиконання у повному об'ємі екологічних функцій (очищення поверхневих і грунтових вод, біогеохімічне перетворення чужорідних матеріалів, регулювання газового складу атмосфери та ії очищення, збереження безперервності біологічного кругообігу тощо). Навпаки, грунт перетворюється на детонатор забруднення води, рослин, повітря.

Останнім часом посилюється увага до вивчення особливостей морфологічної будови міських грунтів [1]. Дослідники відзначають важливу роль насипних грунтів. Під впливом часу їх верхня частина за своїми характеристиками набуває рис акумулятивного горизонту. Поховані горизонти темніші внаслідок акумуляції органічного матеріалу, мають пухкішу будову, містять підвищену кількість коріння та тваринного населення.

\section{Матеріал і методи досліджень}

Нами досліджено наступні морфологічні, фізико-механічні та хімічні властивості грунтів Північної технозони м. Кременчук: щільність твердої фази, щільність і пористість грунту, гранулометричний склад, катіонообмінна здатність, $p H$ грунтового розчину, вміст водорозчинних солей, вміст гумусу, ємність поглинання, ступінь насиченості основами. На основі отриманих результатів із використанням класифікацій міських грунтів М. М. Строганової [6], грунтів України Д. Г. Тихоненко [7], адапто-

(C) I. I. Сараненко, Н. М. Цвєткова, А. О. Дубина, 2007

Вісник Дніпропетровського університету. Біологія, екологія.

Vìsnik Dnìpropetrovs'kogo unìversitetu. Seriâ Bìologîa, ekologîâ Visnyk of Dnipropetrovsk University. Biology, ecology. Vìsn. Dnìpropetr. Unìv. Ser. Bìol. Ekol. 2007. 15(1).

ISSN 2310-0842 print ISSN 2312-301X online www.ecology.dp.ua 
ваних А. П. Травлєєвим і О. В. Мірзак [4] до степової зони України, встановлено підтипи грунтів міста. Забудова міста Кременчук Полтавської області відповідає кластерному типу [3], тобто промислові та побутові споруди згруповані та розташовані на відстані менше ніж 2 км, окрім північної частини. Залежно від характеру виробництва та географічного розташування підприємств, у місті виділено п'ять технозон: південна, північна, східна, західна та цетральна. У кожній із них відокремлені: промислова, селитебна (або промислово-селитебна) та рекреаційна підзони.

На території міста закладено 20 пробних площ. Головний об'єкт дослідження компонент лісових культурбіоценозів міста - грунт. Аналіз морфологічних, фізикомеханічних і хімічних властивостей грунтів проводився за загальноприйнятими методиками $[1 ; 2]$. Фоновою територією обрано парк ім. І. Ф. Котлова, площею близько 10 га, розташований на правому березі р. Дніпро. Парк ім. І. Ф. Котлова розташований на достатній відстані від промислових підприємств.

\section{Результати та їх обговорення}

ПП 107-У. Парк ім. І. Ф. Котлова - фонова територія. Морфологічна будова грунтового профілю:

0-25 см - темно-сірий, сухуватий суглинок зернисто-пилуватої структури, слабо ущільнений, корененасичений, присутні одиничні включення побутового сміття, перехід поступовий;

25-43 см - сірий, свіжуватий середній суглинок грудочкувато-зернистої структури, корененасичений, з одиничними включеннями побутового сміття, перехід поступовий;

43-68 cм - бурий, свіжуватий середній суглинок грудочкуватої структури, злегка ущільнений, корененасиченість невелика, перехід поступовий;

68-120 см - буро-палевий важкий суглинок, структура не виражена.

Грунт слабоущільнений $(V=1,4$ г/см), щільність твердої фази грунту $d=2,4$ г $/ \mathrm{cm}^{3}$, пористість - $42 \%$. За гранулометричним складом - суглинок середній (фізичний пісок - 59,4 \%, фізична глина - 40,6 \%). Вміст катіонообмінного кальцію $84,9 \%$ від ємності поглинання (17,4 мг/екв.), тобто грунт добре оструктурений. $\mathrm{Mg}^{2+}-13,04 \%, \mathrm{Na}^{+}-0,69 \%, \mathrm{~K}^{+}-0,32 \%, \mathrm{H}^{+}-4,02 \%, \mathrm{pH}-7,60$ (слаболужна реакція), грунт насичений основами (ступінь насиченості 92,2 \%), не засолений (вміст водорозчинних солей $-0,19 \%$ ). Вміст гумусу достатньо високий (максимальний по місту) - 7,4 \%. Назва грунту - культурозем малопотужний, малогумусний, слабопорушений, слаболужний, слабозасмічений (з антропогенними включеннями до $25 \%$ ), середньоущільнений, потенційно родючий, $C a$-гумусовий, агрозем дерновий, на чорноземі типовому малогумусному.

Грунт парку ім. І. Ф. Котлова має найсприятливіші умови для росту та розвитку рослин і характерні фізико-механічні та хімічні властивості: найвищий показник вмі-

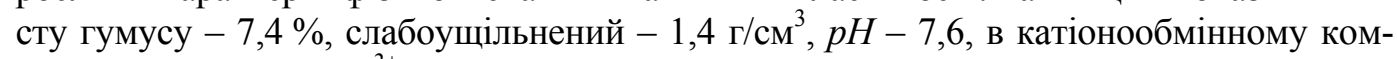
плексі переважає $\mathrm{Ca}^{2+}$, насичений основами, не засолений, ємність поглинання 17,4 мг-екв. Морфологічна будова грунтового профілю свідчить про його відносну цілісність (антропогенні включення менше $25 \%$, тільки у верхньому шарі грунту) та відповідає чорноземам типовим малогумусним.

Властивості міських грунтів необхідно досліджувати саме як компонент кругообігу навколишнього середовища, враховуючи потужність антропогенного фактора. Територія Північної технозони розподілена на рекреаційну (ПП 101-У - парк Воїнівінтернаціоналістів), промислову (ПП 102-У - ТЕЦ, ПП 103-У - Укртатнафта, ПП 104-У - Завод технічного вуглецю) та селитебну підзону (ПП 119-У - проспект 50-річчя Жовтня). Характеристика пробних площ і морфологічні особливості грунтових профілів даної технозони наведені нижче.

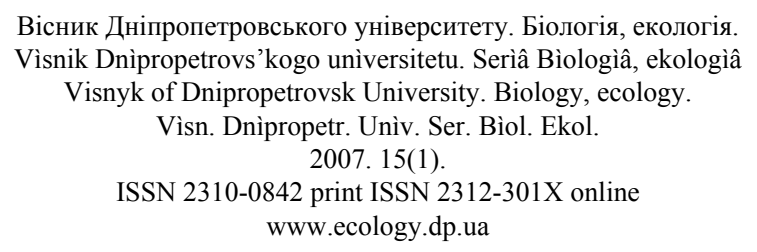


ПІП 101-У. Парк Воїнів-інтернаціоналістів. Морфологічна будова грунтового профілю наступна:

0-20 см - темно-сірий сухуватий легкий суглинок, слабогумусований, дрібнозернисто-пилуватої структури, корененасичений, присутні одиничні включення побутового сміття, перехід чіткий;

20-50 см - сірий свіжуватий легкий суглинок крупнозернистої структури з пилуватістю, присутні кореневі системи, одиничні включення, сміття, межа між горизонтами чітка;

50-70 см - світло-бурий свіжуватий легкий суглинок грудочкуватої структури, зустрічаються одиничні кореневі системи, перехід чіткий;

70-120 см - сірувато-бурий з чорними фрагментами порушений свіжий безструктурний середній суглинок;

120 см ... - лесоподібний суглинок.

Грунти даної пробної ділянки слабоущільнені. Щільність непорушеного грун-

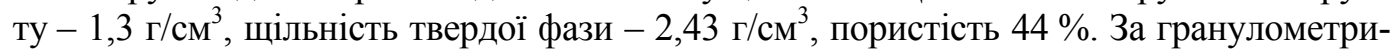
чним складом належить до суглинку легкого крупнопилуватого: фізичний пісок $73,5 \%$, фізична глина - 26,5 \%. Грунти добре оструктурені, сприятливі, фізичні властивості при ємності поглинання - 47,15 мг-екв./100 г грунту. Вміст обмінного $\mathrm{Ca}^{2+}$ 49,90 мг/екв., що складає $91 \%$ від ємності поглинання $(E)$. Кількість $\mathrm{Mg}^{2+}-2,90$ $(6,2 \%), \mathrm{Na}^{+}-0,29(0,61 \%), K^{+}-0,56$ мг/екв. $(1,18 \%$ від $E)$. Грунти достатньою мірою насичені основами - 99, $1 \%, p H$ зміщена у лужний бік $(8,3)$. Вміст водорозчинних солей складає $0,18 \%$ (не засолені грунти), гумусу - 2,04\% (утричі менший за фон). Назва грунту - культурозем малопотужний, малогумусний, середньозасмічений (з антропогенними включеннями до $25 \%$ ), слаболужний, не засолений, $C a$-гумусовий, агрозем дерновий.

ПП 102-У. Штучний біогеоценоз, розташований на відстані 2 км від ТЕЦ. Грунт:

0-20 см - темно-сірий сухуватий легкий суглинок, слабогумусований, задернований, пилуватозернистої структури, перехід поступовий, насичений коренями;

20-50 см - сірий середній суглинок слабоущільненої структури, корененасиченість значно менша, чіткий перехід;

50-70 см - буруватий свіжуватий середній суглинок, перемішаний із сміттям;

70-120 см - бурий свіжий важкий суглинок, без явно вираженої структури.

За гранулометричним складом грунти ПП 102-У належать до суглинку легкого крупнопилуватого (фізичний пісок - 78,1 \%, фізична глина - 21,9\%). Грунти пухкі та слабо ущільнені. Пористість $53 \%$ при щільності непорушеного грунту $-1,29$ г/ $\mathrm{cm}^{3}$ i

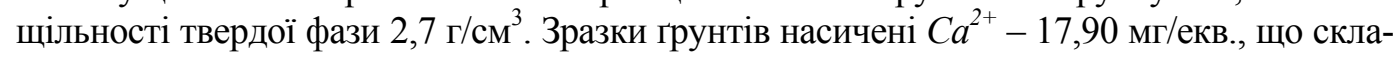
дає - 93,3 \% від ємності поглинання (19,23 мг/екв.). Обмінний магній відсутній. Вміст $\mathrm{Na}^{+}-0,88, \mathrm{~K}^{+}-3,43, H^{+}-2,13 \%$ від $E$. Ступінь насиченості основами складає $-97,7 \%$. $p H-8,24$ (реакція лужна). Грунти не засолені (вміст водорозчинних солей $0,25 \%$ ). Вміст гумусу понижений - 1,59 \% (у 4,5 раза менший за фоновий). Назва грунту - урбодерновий грунт, малопотужний, малогумусний, середньозасмічений (з антропогенними включеннями до 40 \%), слабопорушений, слаболужний, незасолений, слабоущільнений, середньопридатний і середньотоксичний, $C a$-гумусовий, агрозем дерновий.

ПП 103-У. Штучний біогеоценоз на відстані 1,5 км від Укртатнафти. Морфологічна будова грунтового профілю наступна:

0-50 см - темно-сірий із вкрапленням бурого, безструктурний сухуватий легкий суглинок, будівельних відходів - до $50 \%$, горизонт порушений;

50-130 см - колір - від сірого до жовтого, чергування супіщаних і суглинистих шарів, безструктурний, будівельних відходів - 30-40 \% (щебінь), горизонт перемішаний, має нерівношаруватий вигляд; 130-215 см - сірий гумусований пісок, безструктурний, одиничні включення будівельного сміття.

Вісник Дніпропетровського університету. Біологія, екологія.

Vìsnik Dnìpropetrovs'kogo unìversitetu. Serìa Bìologiâ, ekologîâ Visnyk of Dnipropetrovsk University. Biology, ecology. Vìsn. Dnìpropetr. Unìv. Ser. Bìol. Ekol. 2007. 15(1).

ISSN 2310-0842 print ISSN 2312-301X online www.ecology.dp.ua 
Грунти цієї пробної площі слабоущільнені, пористість 37 \% при щільності непорушеного грунту $-1,38 \Gamma / \mathrm{cm}^{3}$ та щільності твердої фази $-2,20 \mathrm{r} / \mathrm{cm}^{3}$. За гранулометричним складом - суглинок легкий крупнопилуватий (фізичний пісок $-72,6 \%$, фiзична глина $-27,4 \%$ ), не засолений (вміст водорозчинних солей $-0,2 \%$ ), насичений основами (ступінь насиченості основами - 82,0\%), вміст гумусу низький $(3,46 \%-$ удвічі менший за фоновий). Смність поглинання -29,22 мг/екв. Реакція грунтового розчину $(p H)$ слабокисла - 6,76 (фон - 7,60). У поглинальному комплексі досліджуваних грунтів виявлений обмінний водень - 5,25 мг/екв., що свідчить про прогресуючі процеси окислення. Грунти слабо структурні. Катіонів $\mathrm{Ca}^{2+}-71,7 \%$ від ємності поглинання (20,9 мг/екв.), $\mathrm{Mg}^{2+}-2,8 \%$ (0,8 мг/екв.), $N a^{+}-1,4 \%$ від $E(0,42$ мг/екв.). Назва грунту індустрозем малопотужний, сильнозасмічений, слабогумусний (з антропогенними включеннями до $50 \%$ ), слабокислий, не засолений, слабоущільнений, придатний і родючий, $C a$-гумусовий, $H$-гумусовий, агрозем буроземно оглеєний.

ПП 104-У. Штучний біогеоценоз на відстані 1 км від Заводу технічного вуглецю. Морфологічна будова грунтового профілю така:

0-50 см - темно-сірий свіжуватий легкий суглинок нормальної щільності, грудкуватої структури (антропогенні включення - 40 \%), насичений коренями, перехід різкий;

50-80 см - сірий свіжуватий середній суглинок грудкуватої структури (антропогенні включення до 20 \%), кореневі системи зустрічаються одинично, перехід поступовий;

80-120 см - бурувато-сірий свіжуватий важкий суглинок без явно вираженої структури.

Грунт нормальної щільності $(0,99$ г/см³ $)$, пористий, пухкий $(\mathrm{P}-60,4$ \%), щільність твердої фази $-2,5$ г/см³. За гранулометричним складом - суглинок легкий крупнопилуватий (фізичний пісок - 78,2\%, фізична глина $-21,8 \%$ ): малогумусний $(2,76 \%$ - у 2,6 раза менше за фон), не засолений (вміст водорозчинних солей $0,18 \%)$, насичений основами (ступінь насиченості - 97,1 \%), $p H-8,26$ (слаболужна реакція). Ємність поглинання - 14,99\% (найнижча по місту). Вміст $\mathrm{Ca}^{2+}-13,3$ мг/екв., що складає 89,1\% від ємності поглинання, кількість $M g^{2+}$ незначна $(0,4$ мг/екв., або $3,20 \%$ від $E$ ). $N a^{+}-0,24$ мг/екв. або 2,66\% від $E, H^{+}-0,44$ мг/екв. або 2,93\% від $E$. Грунти оструктурені, збагачені поживними речовинами. Назва грунту - індустрозем малопотужний слабогумусний середньозасмічений (з антропогенними включеннями - 40 \%), слаболужний, не засолений, нормальної щільності, середньопридатний та середньотоксичний, $C a$-гумусовий, агрозем дерновий.

ПІІ 119-У. Газон, розташований на проспекті 50-річчя Жовтня. Морфологічна будова грунтового профілю наступна:

0-20 см - темно-сірий сухуватий легкий суглинок, сильноущільнений, слабогумусований, горіхувато-пилуватої структури, присутні кореневі системи, перехід поступовий;

20-50 см - сірий свіжуватий середній суглинок, грудочкуватої структури, корені зустрічаються одинично, включення сміття - $25 \%$, межа між горизонтами чітка;

50-70 см - темно-палевий свіжуватий середній суглинок, горіхувато-грудочкуватої структури, кореневі системи відсутні;

70-120 см - палевий важкий суглинок, перемішаний, безструктурний.

За гранулометричним складом суглинок легкий, крупнопилуватий (фізичний пісок $-74,6 \%$, фізична глина $-25,4 \%$ ). Грунт сильноущільнений: $V-1,5$ г/см ${ }^{3}$, $d-2,25$ г $\mathrm{cm}^{3}$, пористість - 30,0\%. Грунт оструктурений, насичений поживними речовинами. У катіонообмінному комплексі переважає $\mathrm{Ca}^{2+}-88,0 \%$ від ємності поглинання (23,63 мг/екв.), $\mathrm{Mg}^{2+}-3,7 \%, K^{+}-2,8 \%, H^{+}-3,3 \%$ від $E$. Зразки проб насичені основами (ступінь насиченості - 94,5\%), не засолені (вміст водорозчинних солей $0,15 \%), p H-7,52$ (близько до нейтральної реакції), вміст гумусу низький $-2,8 \%$ (у 2,5 раза менший за фон).

Вісник Дніпропетровського університету. Біологія, екологія.

Vìsnik Dnìpropetrovs'kogo unìversitetu. Serìa Bìologiâ, ekologîâ Visnyk of Dnipropetrovsk University. Biology, ecology. Vìsn. Dnìpropetr. Unìv. Ser. Bìol. Ekol. 2007. 15(1).

ISSN 2310-0842 print ISSN 2312-301X online www.ecology.dp.ua 


\section{Висновки}

У результаті дослідження основних фізико-хімічних і морфологічних властивостей грунтів північної технозони м. Кременчук з'ясовано, що природний грунтовий покрив на більшій частині технозони знищений або значно змінений: переущільнення, перемішування майже всіх шарів грунтового профілю, вміст антропогенних включень 25-50\%. Істотне місце займають насипні грунти з легким гранулометричним складом. Залежно від потужності антрогенних факторів змінюються фізикохімічні властивості, $p H$ перебуває в межах $6,7-8,3$, вміст гумусу в грунтах промислової та селитебної підзон у 1,5 раза нижчий, ніж у рекреаційній та у 5 разів нижчий, ніж у грунтах фонової території. Ємність поглинання зменшується удвічі, кількість поглинутого водню збільшується з 0,9 до $19,9 \%$.

На території Північної технозони на основі класифікації міських грунтів М. М. Строганової, грунтів України Д.Г. Тихоненка та методичних рекомендацій А. П. Травлєєва та О. В. Мірзак установлені наступні підтипи грунтів: індустроземи, культуроземи, урбодернові грунти, ристоземи.

\section{Бібліографічні посилання}

1. Агаркова М. Г. Морфологические особенности городских почв и их систематика / М. Г. Агаркова, Л. К. Мелешева, М. Н. Строганова // Вестник Моск. ун-та. Серия 17 Почвоведение. - 1991. - С. 11-16.

2. Аринушкина Е. В. Руководство по химическому анализу почв. - М.: МГУ, 1970. -487 с.

3. Злобін Ю. А. Основи екології. - К.: Лібра, 1998. - С. 40-47.

4. Мірзак О. В. Екологічні особливості едафотопів урбанізованих територій // Екологія та ноосферологія. - 2001. - Т. 10, № 1-2. - С. 71-81.

5. Прокофьева Т. В. Городские почвы, запечатанные дорожными покрытиями (на примере г. Москвы). Автореф. дис. ... канд. биол. наук. - М.: МГУ, 1998. - 24 с.

6. Строганова М. Н. Городские почвы: генезис, систематика и экологическое значение (на примере г. Москвы). Автореф. дис. ... д-ра биол. наук. - М., 1998. - 71 с.

7. Тихоненко Д. Г. До питання про класифікацію грунтів України // Грунтознавство. 2001. - Т. 1, № 1-2. - С. 15-22.

8. Травлеев А. П. Материалы к номенклатуре и классификации лесных почв подзоны настоящих степей // Вопросы степного лесоведения. - Д.: ДГУ, 1972. - Вып. 3. - С. 16-22.

9. Хакимов Ф. И. Эколого-геохимическая характеристика почв промышленного города / Ф. И. Хакимов, Н. Ф. Деева, А. А. Ильина // Экология и почвы. Избранные лекции I-VII Всероссийских школ. - Пущино: ОНТИ ПНЦ РАН, 1998. - С. 182-205.

10. Хрусталева М. А. Миграция микроэлементов в компонентах ландшафтов центрального Нечерноземья в зависимости от антропогенного воздействия / М. А. Хрусталева, В. С. Коржевская // Миграция загрязняющих веществ в почвах и сопредельных средах. Л.: Гидрометеоиздат, 1989. - С. 200-206.

Надійшла до редколегї 15.01.2007

Вісник Дніпропетровського університету. Біологія, екологія.

Vìsnik Dnìpropetrovs'kogo unìversitetu. Serîâ Bìologîa, ekologiâ Visnyk of Dnipropetrovsk University. Biology, ecology. Vìsn. Dnìpropetr. Unìv. Ser. Bìol. Ekol. 2007. 15(1).

ISSN 2310-0842 print ISSN 2312-301X online www.ecology.dp.ua 